\title{
Outcomes of Trabeculectomy in Africa
}

\author{
Joella Eldie Soatiana ${ }^{1}$, Marce-Amara Kpoghoumou ${ }^{2}$, Fatch W. Kalembo ${ }^{3}$, Huyi Zhen ${ }^{1}$ \\ ${ }^{1}$ Department of Ophthalmology, Tongji Medical College of Huazhong University of Science and Technology, Wuhan, China; ${ }^{2}$ Depart- \\ ment of Epidemiology and Biostatistics, Tongji Medical College of Huazhong University of Science and Technology, Wuhan, China; \\ ${ }^{3}$ Department of Maternal and Child Health, Tongji Medical College of Huazhong University of Science and Technology, Wuhan, China. \\ Email: joellaeldie@yahoo.fr; kpogmarce@yahoo.fr; kalembofatch@yahoo.com;1012646376@qq.com
}

Received April 13 ${ }^{\text {th }}, 2013$; revised May 14 ${ }^{\text {th }}, 2013$; accepted June 20 ${ }^{\text {th }}, 2013$

Copyright (C) 2013 Joella Eldie Soatiana et al. This is an open access article distributed under the Creative Commons Attribution License, which permits unrestricted use, distribution, and reproduction in any medium, provided the original work is properly cited.

\begin{abstract}
Purpose: To determine the outcome of trabeculectomy in African countries. Design: This is a review of literature for trabeculectomy conducted in Africa from 2000 to December 2012. Methods: We conducted an electronic search from the following databases: PubMed, Science Direct, Google, and Google scholar websites for the articles of original studies on trabeculectomy conducted in Africa. Results: A total of 109 articles, published from 2000 to December 2012 were retrieved. Only 12 articles met our inclusion criteria and were included in the study. The follow-up duration ranged from 6 months to 60 months. The post-trabeculectomy IOP range was $10 \mathrm{mmHg}$ to $22 \mathrm{mmHg}$ with rates varying from $61.8 \%$ to $90 \%$. The visual acuity was unchanged among $19 \%$ to $30 \%$ of the participants in the last follow-up, and the improvement rate was $36 \%$ to $81.5 \%$ while those whose condition worsened ranged from $8.9 \%$ to $30.8 \%$. The cup-disc ratio was $\leq 0.5$ in $13 \%$ and $\geq 0.8$ in $83 \%$ of the participants. The failure rate of the $\mathrm{c} / \mathrm{d}$ ratio was 0.9 and it increased by 0.027 units. There was a follow-up of only one study on the visual field. Conclusion: Trabeculectomy with or without application of antimetabolite appears to be a good way to lowering the IOP in Africa. In addition, the combined effect of trabeculectomy and cataract surgery produces visual benefits for the patients.
\end{abstract}

Keywords: Trabeculectomy; Glaucoma; Africa

\section{Introduction}

Glaucoma is one of the most common causes of blindness in the world [1] and it causes irreversible visual loss [2]. This aspect is well known for the developed countries, however in Africa blindness mainly occurs due to cataract, trachoma and onchocercosis. Glaucoma is not mentioned enough. Patients present with severe findings after a long-lasting history of disease [1]. Data available from the United States and Barbados suggest that blacks (mostly of West African origin) are 4 - 8 times more likely to have glaucoma than whites and more likely to be blind due to glaucoma compared with the white population $[3,4]$. Treatment is difficult due to the unavailability and expensiveness of glaucoma medication [5]. This makes surgery for glaucoma an attractive option. Trabeculectomy is also a well recognized treatment option for the surgical management of raised intraocular pressure (IOP) [6]. It has been reported to be more beneficial in Africans in terms of IOP lowering effect and slowing down of field loss $[7,8]$ and has been reported to have some benefit in black people in Africa and the Caribbean area
$[9,10]$. Wound healing modulating agents, usually antimetabolites like 5-Fluorouracil and Mitomycin $\mathrm{C}$ which inhibit the natural healing response and scar formation are used to reduce trabeculectomy failure [11]. Primary trabeculectomy with MMC using a fornix-based conjunctival flap technique is an effective treatment for Thai glaucoma patients. Mean IOP was significantly decreased from $26.1+11.7 \mathrm{mmHg}$ to $11.7+4.4 \mathrm{mmHg}(\mathrm{p}<$ $0.001)$ at the last visit. At the last follow up period, 67 eyes $(97.1 \%)$ were considered as success [12]. Wilkins and Wormald and their respective colleagues reported that the addition of antimetabolites to trabeculectomy reduced IOP among participants enrolled in their studies [13].

We decided to perform a systematic review in order to determine the outcome of trabeculectomy in African countries.

\section{Materials and Methods}

\subsection{Search Strategy}

A search strategy was designed to identify publications 
which described trabeculectomy in Africa. The search was conducted from November to December 2012. We conducted an electronic search from the following databases: PubMed, ScienceDirect, Google, and Google scholar websites. The following search terms were used "trabeculectomy in Africa", "treatment of glaucoma in Africa", "follow-up of trabeculectomy in Africa".

\subsection{Inclusion/Exclusion Criteria}

Articles were included in the review if they met the following criteria: 1) they were conducted in Africa and covered trabeculectomy in Africa; 2) they covered our objective; 3) they were published in English; 4) they were published from 2000 to December 2012. Articles were excluded from the review if: 1) they were conducted outside African countries; 2) the trabeculectomy conducted in Africa was associated with another surgery other than cataract surgery; 3 ) the articles were conducted in Africa and covered trabeculectomy in Africa but we did not have access to the full text. Types of outcome measures: The main outcome measures of the study were intraocular pressure (IOP) reduction, visual acuity (VA), visual field (VF) and cup-disc (c/d) ratio.

\subsection{Data Extraction}

Two authors independently viewed the titles and abstracts of all the studies identified in the electronic searches. All methodological steps followed the guide- lines set by QUOROM statement criteria [14]. The full copies of all possibly relevant studies were obtained and independently inspected by two authors to determine whether they met the inclusion criteria. When a difference in opinion occurred, a third reviewer was consulted, as an arbiter. The authors of the selected studies were contacted to elucidate any doubts, when necessary. Included articles were studied for relevance and content. Data was extracted under the following areas: first author, year of publication, country of study, study population, study objectives, research methods and interventions. The main findings of each study were summarized.

\subsection{Data Analysis}

The data for analysis and synthesis were the study methods, findings, and conclusion.

\section{Results}

\subsection{Eligible Studies}

For trabulectomy outcomes in Africa, articles were retrieved based on the search criteria above. Study selection process is shown in Figure 1. The electronic searches retrieved 109 citations, all citations were screened and 30 full text articles were retrieved for further as- sessment. A total of 18 articles were excluded because they were not conducted in sub-Saharan Africa, some of them were not about trabeculectomy in Africa and a number of them were not published in English. Finally, a total of 12 studies including 947 patients were eligible for the review. Study characteristics are summarized in Table 1.

\subsection{Main Outcomes}

Articles reviewed were drawn from 5 sub-Saharan countries (Nigeria, South Africa, Tanzania, Ghana, and Kenya). There were 2 articles which used 5 FU during surgery [15,20], 2 articles used mitomycin $C$ during the surgery [17,23], 3 articles did not use the antimetabolite during the surgery $[11,18,21], 5$ articles were on comparative study, of those 4 compared between using 5FU and non antimetabolites surgeries [16,19,22,24] and 1 was on comparison between using these 2 antimetabolites (5FU and MMC)[25]. Among the articles, 4 were on trabeculectomy combined with cataract surgery $[15,20$, 23,24]. The duration of the last follow-up was 6 months to 60 months. The outcomes of the study were: 1) outcome of IOP post-trabeculectomy; 2) outcome of VA post-trabeculectomy; 3) outcome of the cup-disc ratio and the visual field post-operative.

- Outcome of IOP post-trabeculectomy. There was a success during the control of IOP for all the studies with a range of $10 \mathrm{mmHg}$ to $22 \mathrm{mmHg}$ and the rates varied from $61.8 \%$ to $90 \%$.

- Outcome of VA post-trabeculectomy. The VA was unchanged among $19 \%$ to $30 \%$ of the participants in the last follow-up, VA improvement rate was between $36 \%$ to $81.5 \%$ and worsened in $8.9 \%$ to $30.8 \%$ of the

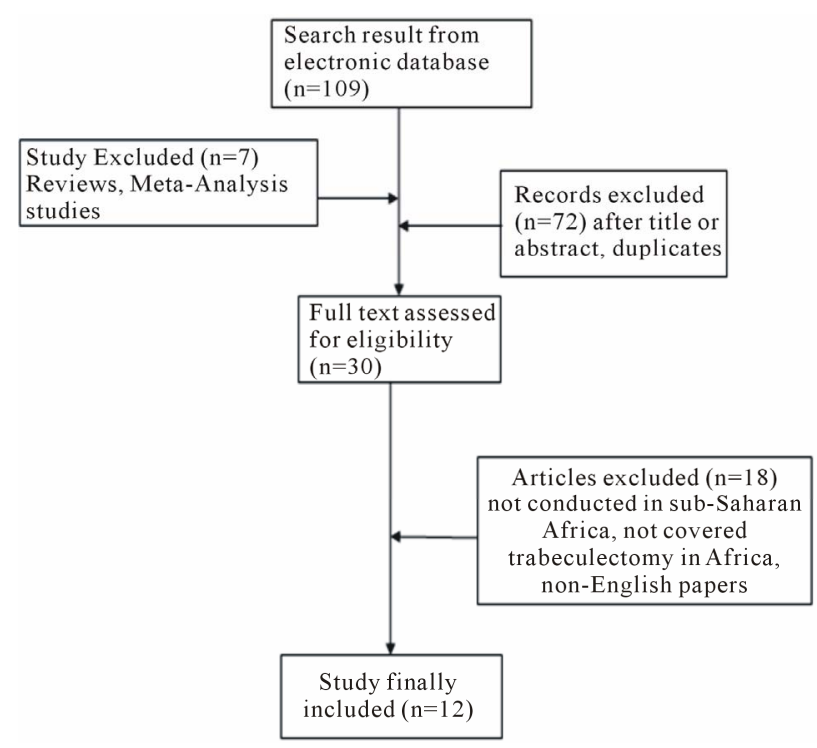

Figures 1. Flow chart of study selection based on the inclusion and exclusion criteria. 
Table 1. Summary of studies of the outcome of trabeculectomy in Africa.

\begin{tabular}{|c|c|c|c|c|}
\hline $\begin{array}{c}\text { First } \\
\text { author, } \\
\text { area, year }\end{array}$ & $\begin{array}{c}\text { Study } \\
\text { population }\end{array}$ & $\begin{array}{c}\text { Study design } \\
\text { and methodology }\end{array}$ & Interventions & Outcomes \\
\hline
\end{tabular}

$\begin{array}{lll}\text { A.Lawan, } & 71 \text { eyes, } & \begin{array}{l}\text { Retrospective } \\ \text { Trabeculectomy with } \\ \text { Nigeria, }\end{array} \\ \text { 2007 [15] patients } & \text { POAG } & \begin{array}{l}\text { application of antimetabolite. } \\ 21 \% \text { of them associated with } \\ \text { cataract surgery }\end{array}\end{array}$
$\begin{array}{ll}\text { with } & \text { antimetabolite, } 73.59 \%\end{array}$

B.O, Nigeria primary

2007 [16] glaucoma

and $12.5 \%$

secondary

glaucoma

Retrospective IOP was measured and followed-up from day 1 to 12 months. $26.4 \%$ of the patients had trabeculectomy with application of had trabeculectomy without application of antimetabolite. The outcome of the surgery was classified as complete success if post operative IOP at one year was $20 \mathrm{mmHg}$ or less without anti-glaucoma medication

Retrospective

Trabeculectomy with application of antimetabolite.

43 eyes 41 The last follow-up was at

Manners T, patients 60 months postoperative

South Africa, Traumatic with a mean of 25

2001 [17]

angle

recession

glaucoma months. The outcome of

the surgery was classified

as "complete success"

when the IOP was $<21$

$\mathrm{mm} \mathrm{Hg}$ without

glaucoma medication

Retrospective $36 \%$ of the participant had trabeculectomy with application of antimetabolite. Mean follow-up was 8 months.
VA as measured with Snellen`s or,Illiterate "C" $\mathrm{c} / \mathrm{d}$ ratio was assessed with direct ophthalmoscope. IOP was measured with the applanation tonometer Perimetry was done with the $2 \mathrm{~m}$ Tangent screen using a $5 \mathrm{~mm}$ white target Administration of $5 \mathrm{FU}$ as antimetabolite

Measuring of VA and IOP Administration of $5 \mathrm{FU}$ as antimetabolite

Measuring of VA and IOP Administration of MMC as antimetabolite

Measuring of VA and IOP Administration of $5 \mathrm{FU}$ as antimetabolite
Good intraocular pressure contro $82 \%$ of participants had IOP of 10 to $15 \mathrm{mmHg}, 15 \%$ had 16 to $20 \mathrm{mmHg}$. $19 \%$ of the patients had VA of $6 / 6-$ $6 / 18$ before and after surgery, $51 \%$ had visually impaired after surgery, 29\% had severe visual impairement and $1 \%$ was blind. $13 \%$ had $\mathrm{c} / \mathrm{d}$ ratio $\leq$ $0.5,54 \%$ had c/d ratio $=0.6-0.8$ and $33 \%$ had c/d ratio $=0.9$. The perimetry result showed that $7 \%$ of the participants had peripheral field constriction of $10-20^{\circ}, 27 \%$ had both peripheral field constriction and arcuate scotoma, $48 \%$ had visual field of $30^{\circ}$ and less $\left(\leq 30^{\circ}\right)$ and $18 \%$ had ability to fixate on target.
Complete success was obtained in $61.8 \%$ of the participants at 12 months. High success rate for the both. The mean post-operative IOP in the 5FU-augmented cases was significantly lower compared with the non augmented cases $(P=0.005)$. There were no significant changes in the VA during the follow-up period.
Tanzania, 2005 [18]
At last follow-up, there was $76.7 \%$ of complete success for the IOP. For the VA, at last follow-up ranged from $6 / 9$ to no light perception, the visual outcome was the same or better in $81.5 \%$.
$73 \%$ had IOP of $15 \mathrm{~mm} \mathrm{Hg}$ or less at latest follow-up (mean follow-up was 8.7 months) and $90 \%$ had IOP of $21 \mathrm{~mm} \mathrm{Hg}$ or less (mean follow-up was 8.8 months). $25 \%$ patients lost VA at least 2 lines of Snellen acuity or equivalent between preoperative measurement and latest follow-up. 


\begin{tabular}{|c|c|c|c|c|}
\hline $\begin{array}{l}\text { Gyasi M.E., } \\
\text { Ghana, } 2006 \\
{[11]}\end{array}$ & $\begin{array}{l}191 \text { eyes } \\
164 \\
\text { patients } \\
96.8 \% \\
\text { POAG } \\
3.2 \% \\
\text { normal } \\
\text { tension } \\
\text { glaucoma } \\
\text { (NTG) }\end{array}$ & $\begin{array}{l}\text { Retrospective } \\
\text { Trabeculectomy without } \\
\text { application of antimetabolite } \\
\text { Follow-up period was } \\
\text { grouped into } 4 \text { categories: the } \\
\text { first post-operative month, } \\
\text { between the second and } \\
\text { third months, fourth to } \\
\text { fifth month and the sixth } \\
\text { month and beyond Control } \\
\text { IOP was only made in POAG } \\
\text { patient. Successful IOP } \\
\text { control defined as IOP less } \\
\text { than } 22 \text { mmHg or a reduction } \\
\text { of } 30 \% \text { if pre-operative } \\
\text { pressure was already less } \\
\text { than } 22 \text { mmHg. }\end{array}$ & $\begin{array}{l}\text { IOP was measured with } \\
\text { standard Goldman } \\
\text { applanation tonometer }\end{array}$ & $\begin{array}{l}\text { Statistically significant difference between the mean } \\
\text { pre-op and post-op IOP }(\mathrm{p}=0.001) \text { with success of } \\
88.46 \% \text { of the eyes which had post-operative IOP }< \\
22 \mathrm{mmHg} \text { at the last examination at six months. } \\
\text { In eyes with NTG only } 16.7 \% \text { achieved a successful } \\
30 \% \text { target pressure reduction with post-op IOP of } \\
8 \mathrm{mmHg} \text {. }\end{array}$ \\
\hline $\begin{array}{l}\text { Yorston D, } \\
\text { Kenya, } 2001 \\
{[19]}\end{array}$ & $\begin{array}{l}68 \text { eyes } \\
68 \text { patients } \\
\text { Chronic } \\
\text { open angle } \\
\text { glaucoma }\end{array}$ & $\begin{array}{l}\text { Prospective Some patients } \\
\text { had trabeculectomy with } \\
\text { application of antimetabolite. } \\
\text { Major outcome measures } \\
\text { were IOP at } 6 \text { months } \\
\text { and probability of failure at } 2 \\
\text { years. Failure was defined as } \\
\text { a pressure of more than } 26 \\
\text { mm Hg on one occasion, } \\
\text { or a pressure of between } \\
22 \text { and } 26 \text { mm Hg on two } \\
\text { occasions at least } 2 \text { months } \\
\text { apart. }\end{array}$ & $\begin{array}{l}\text { Measuring of IOP and VA } \\
\text { Administration of } 5 \mathrm{FU} \text { as } \\
\text { antimetabolite }\end{array}$ & $\begin{array}{l}\text { The mean IOP was } 17.4 \mathrm{~mm} \mathrm{Hg} \text { in the placebo } \\
\text { group and } 16.9 \mathrm{mmHg} \text { in the } 5 \text {-FU group after } 180 \\
\text { days of surgery. } \\
\text { By } 2 \text { years after trabeculectomy, the probability of } \\
\text { successful IOP control was } 70.6 \% \text { in the placebo } \\
\text { group, and } 88.8 \% \text { in the } 5 \text {-FU group. } \\
\text { Among patients followed for } 2 \text { years, } 30 \% \text { lost } 0.3 \\
\text { logMAR units of visual acuity. }\end{array}$ \\
\hline $\begin{array}{l}\text { Bowman RJC, } \\
\text { Tanzania, } \\
2010[20]\end{array}$ & $\begin{array}{l}163 \text { eyes } \\
163 \\
\text { patients } \\
\text { with } \\
\text { Advanced } \\
\text { glaucoma }\end{array}$ & $\begin{array}{l}\text { Retrospective } 80 \% \\
\text { Trabeculectomy } \\
\text { combined with cataract } \\
\text { surgery with application } \\
\text { of antimetabolite. IOP } \\
\text { outcomes were analysed } \\
\text { using two success criteria: } \\
\text { follow-up IOP ranges of } \\
6-15 \text { and } 6 \text { - } 20 \mathrm{mmHg} \text {. }\end{array}$ & $\begin{array}{l}\text { Measuring VA and IOP } \\
\text { Administration of } 5 \mathrm{FU} \text { as } \\
\text { antimetabolite }\end{array}$ & $\begin{array}{l}\text { Of those with at least a } 6 \text {-month follow-up, } 58 \% \\
\text { patients and } 84 \% \text { patients had IOPs of } 6-15 \text { and } \\
6-20 \mathrm{mmHg} \text {, respectively. } \\
\text { Mean follow-up IOP was } 15 \mathrm{mmHg} \text {. There was no } \\
\text { significant difference in mean final follow-up IOP } \\
\text { between those with and without } 3 \text { or } 6 \text { months of } \\
\text { follow-up. } \\
70 \% \text { patients had improved their acuity compared } \\
\text { with pre-operation by at least one line; } 40(37 \%) \\
\text { achieved } 6 / 18 \text { or better, and } 71 \\
66 \% \text { achieved } 6 / 60 \text { or better. Of those with at least } \\
3 \text { - and } 6 \text {-month follow-up, } 42 \text { of } 51(82 \%) \text { patients } \\
\text { and } 17 \text { of } 20(85 \%) \text { improved their acuity }\end{array}$ \\
\hline $\begin{array}{l}\text { Anand N, } \\
\text { Nigeria, } 2001 \\
{[21]}\end{array}$ & $\begin{array}{l}142 \text { eyes } \\
100 \\
\text { patients } \\
\text { POAG } \\
(84 \% \\
\text { advanced } \\
\text { glaucoma) }\end{array}$ & $\begin{array}{l}\text { Retrospective } \\
\text { Trabeculectomy without } \\
\text { application of antimetabolite. } \\
\text { Subsequent surgery for } \\
\text { glaucoma and cataract } \\
\text { was noted. Follow-up more } \\
\text { than } 6 \text { months Criteria for } \\
\text { success were an lOP reduction } \\
\text { of more than } 30 \% \text { from } \\
\text { pre-operative levels, a } \\
\text { permanent decrease in } \\
\text { visual acuity of } 2 \text { Snellen } \\
\text { chart lines or less from } \\
\text { pre-operative levels and } \\
\text { 1OP of less than either } 22 \\
\text { mmHg (criterion 1) or } 16 \\
\text { mmHg (criterion } 2 \text { ) with } \\
\text { or without medication. }\end{array}$ & Measuring of VA and IOP & $\begin{array}{l}\text { The cumulative success rates by the first criterion } \\
\text { were } 85 \% \text { at the end of } 1 \text { year, falling to } 71 \% \text { in } 5 \\
\text { years. By the second criterion success rates were } \\
\text { much lower, being } 65 \% \text { at } 1 \text { year and } 46 \% \text { at } 5 \\
\text { years. } \\
\text { Failure of surgery was most frequently in the first } 6 \\
\text { months after surgery but continued at a steady rate } \\
\text { throughout the follow-up period. }\end{array}$ \\
\hline
\end{tabular}




\section{Continued}

\begin{tabular}{|c|c|c|c|c|}
\hline $\begin{array}{l}\text { Gyasi M.E., } \\
\text { Ghana, } 2006 \\
{[11]}\end{array}$ & $\begin{array}{l}191 \text { eyes } \\
164 \\
\text { patients } \\
96.8 \% \\
\text { POAG } \\
3.2 \% \\
\text { normal } \\
\text { tension } \\
\text { glaucoma } \\
\text { (NTG) }\end{array}$ & $\begin{array}{l}\text { Retrospective } \\
\text { Trabeculectomy without } \\
\text { application of antimetabolite } \\
\text { Follow-up period was } \\
\text { grouped into } 4 \text { categories: the } \\
\text { first post-operative month, } \\
\text { between the second and } \\
\text { third months, fourth to } \\
\text { fifth month and the sixth } \\
\text { month and beyond Control } \\
\text { IOP was only made in POAG } \\
\text { patient. Successful IOP } \\
\text { control defined as IOP less } \\
\text { than } 22 \text { mmHg or a reduction } \\
\text { of } 30 \% \text { if pre-operative } \\
\text { pressure was already less } \\
\text { than } 22 \text { mmHg. }\end{array}$ & $\begin{array}{l}\text { IOP was measured with } \\
\text { standard Goldman } \\
\text { applanation tonometer }\end{array}$ & $\begin{array}{l}\text { Statistically significant difference between the mean } \\
\text { pre-op and post-op IOP }(\mathrm{p}=0.001) \text { with success of } \\
88.46 \% \text { of the eyes which had post-operative IOP }< \\
22 \mathrm{mmHg} \text { at the last examination at six months. } \\
\text { In eyes with NTG only } 16.7 \% \text { achieved a successful } \\
30 \% \text { target pressure reduction with post-op IOP of } \\
8 \mathrm{mmHg} \text {. }\end{array}$ \\
\hline $\begin{array}{l}\text { Yorston D, } \\
\text { Kenya, } 2001 \\
{[19]}\end{array}$ & $\begin{array}{l}68 \text { eyes } \\
68 \text { patients } \\
\text { Chronic } \\
\text { open angle } \\
\text { glaucoma }\end{array}$ & $\begin{array}{l}\text { Prospective Some patients } \\
\text { had trabeculectomy with } \\
\text { application of antimetabolite. } \\
\text { Major outcome measures } \\
\text { were IOP at } 6 \text { months } \\
\text { and probability of failure at } 2 \\
\text { years. Failure was defined as } \\
\text { a pressure of more than } 26 \\
\text { mm Hg on one occasion, } \\
\text { or a pressure of between } \\
22 \text { and } 26 \text { mm Hg on two } \\
\text { occasions at least } 2 \text { months } \\
\text { apart. }\end{array}$ & $\begin{array}{l}\text { Measuring of IOP and VA } \\
\text { Administration of } 5 \mathrm{FU} \text { as } \\
\text { antimetabolite }\end{array}$ & $\begin{array}{l}\text { The mean IOP was } 17.4 \mathrm{~mm} \mathrm{Hg} \text { in the placebo } \\
\text { group and } 16.9 \mathrm{mmHg} \text { in the } 5 \text {-FU group after } 180 \\
\text { days of surgery. } \\
\text { By } 2 \text { years after trabeculectomy, the probability of } \\
\text { successful IOP control was } 70.6 \% \text { in the placebo } \\
\text { group, and } 88.8 \% \text { in the } 5 \text {-FU group. } \\
\text { Among patients followed for } 2 \text { years, } 30 \% \text { lost } 0.3 \\
\text { logMAR units of visual acuity. }\end{array}$ \\
\hline $\begin{array}{l}\text { Bowman RJC, } \\
\text { Tanzania, } \\
2010[20]\end{array}$ & $\begin{array}{l}163 \text { eyes } \\
163 \\
\text { patients } \\
\text { with } \\
\text { Advanced } \\
\text { glaucoma }\end{array}$ & $\begin{array}{l}\text { Retrospective } 80 \% \\
\text { Trabeculectomy } \\
\text { combined with cataract } \\
\text { surgery with application } \\
\text { of antimetabolite. IOP } \\
\text { outcomes were analysed } \\
\text { using two success criteria: } \\
\text { follow-up IOP ranges of } \\
6-15 \text { and } 6-20 \mathrm{mmHg} \text {. }\end{array}$ & $\begin{array}{l}\text { Measuring VA and IOP } \\
\text { Administration of } 5 \mathrm{FU} \text { as } \\
\text { antimetabolite }\end{array}$ & $\begin{array}{l}\text { Of those with at least a } 6 \text {-month follow-up, } 58 \% \\
\text { patients and } 84 \% \text { patients had IOPs of } 6-15 \text { and } \\
6-20 \mathrm{mmHg} \text {, respectively. } \\
\text { Mean follow-up IOP was } 15 \mathrm{mmHg} \text {. There was no } \\
\text { significant difference in mean final follow-up IOP } \\
\text { between those with and without } 3 \text { or } 6 \text { months of } \\
\text { follow-up. } \\
70 \% \text { patients had improved their acuity compared } \\
\text { with pre-operation by at least one line; } 40(37 \%) \\
\text { achieved } 6 / 18 \text { or better, and } 71 . \\
66 \% \text { achieved } 6 / 60 \text { or better. Of those with at least } \\
3-\text { and } 6 \text {-month follow-up, } 42 \text { of } 51(82 \%) \text { patients } \\
\text { and } 17 \text { of } 20(85 \%) \text { improved their acuity. }\end{array}$ \\
\hline $\begin{array}{l}\text { Anand N, } \\
\text { Nigeria, } 2001 \\
{[21]}\end{array}$ & $\begin{array}{l}142 \text { eyes } \\
100 \\
\text { patients } \\
\text { POAG } \\
(84 \% \\
\text { advanced } \\
\text { glaucoma) }\end{array}$ & $\begin{array}{l}\text { Retrospective } \\
\text { Trabeculectomy without } \\
\text { application of antimetabolite. } \\
\text { Subsequent surgery for } \\
\text { glaucoma and cataract } \\
\text { was noted. Follow-up more } \\
\text { than } 6 \text { months Criteria for } \\
\text { success were an } 1 \text { OP reduction } \\
\text { of more than } 30 \% \text { from } \\
\text { pre-operative levels, a } \\
\text { permanent decrease in } \\
\text { visual acuity of } 2 \text { Snellen } \\
\text { chart lines or less from } \\
\text { pre-operative levels and } \\
1 \text { OP of less than either } 22 \\
\text { mmHg (criterion } 1 \text { ) or } 16 \\
\text { mmHg (criterion } 2 \text { ) with } \\
\text { or without medication. }\end{array}$ & Measuring of VA and IOP & $\begin{array}{l}\text { The cumulative success rates by the first criterion } \\
\text { were } 85 \% \text { at the end of } 1 \text { year, falling to } 71 \% \text { in } 5 \\
\text { years. By the second criterion success rates were } \\
\text { much lower, being } 65 \% \text { at } 1 \text { year and } 46 \% \text { at } 5 \\
\text { years. } \\
\text { Failure of surgery was most frequently in the first } 6 \\
\text { months after surgery but continued at a steady rate } \\
\text { throughout the follow-up period. }\end{array}$ \\
\hline
\end{tabular}




\section{Continued}

\begin{tabular}{|c|c|c|c|c|}
\hline $\begin{array}{l}\text { Ashaye AO, } \\
\text { Nigeria, 2009 } \\
\text { [22] }\end{array}$ & $\begin{array}{l}76 \text { eyes } 44 \\
\text { patients } \\
92,1 \% \\
\text { POAG } \\
7.9 \% \\
\text { chronic } \\
\text { angle } \\
\text { closure } \\
\text { glaucoma }\end{array}$ & $\begin{array}{l}\text { Retrospective } 32.9 \% \text { had } \\
\text { trabeculectomy with } \\
\text { application of } \\
\text { antimetabolite and } 67.1 \% \\
\text { had trabeculectomy } \\
\text { without antimetabolite } \\
\text { Follow-up for minimum } \\
\text { of } 12 \text { month after surgery }\end{array}$ & $\begin{array}{l}\text { Measuring of IOP } \\
\text { Administration of } 5 \mathrm{FU} \text { as } \\
\text { antimetabolite }\end{array}$ & $\begin{array}{l}\text { The percentage of maintaining IOP of } 21 \mathrm{mmHg} \text { or } \\
\text { less at } 1 \text { year of follow-up was } 79.4 \% \text {. ( } 80.6 \% \text { for } \\
\text { the non-5-FU group and } 76.7 \% \text { for the } 5 \text {-FU group.) } \\
\text { Comparison of the curve by the log-rank test } \\
\text { showed no significant difference between the two } \\
\text { groups }(p=0.136) \text {. }\end{array}$ \\
\hline $\begin{array}{l}\text { Harry A } \\
\text { Quigley, } \\
\text { Tanzania, } \\
2000[23]\end{array}$ & $\begin{array}{l}21 \text { patients } \\
-\end{array}$ & $\begin{array}{l}\text { Prospective Visual acuity was } \\
\text { measured at } 4 \text { metres using a } \\
\text { tumbling E ETDRS chart. } \\
\text { Visual field was measured } \\
\text { using the Dicon LD400 } \\
\text { automated instrument IOP } \\
\text { was measured with calibrated } \\
\text { TonoPen Optic disc area } \\
\text { examined with a hand held, } \\
78 \text { dioptre lens and } 10 x \text { eye } \\
\text { piece of the slit lamp. } 80 \% \text { of } \\
\text { the patients had } \\
\text { trabeculectomy with } \\
\text { application of antimetabolite } \\
25 \% \text { combined with cataract } \\
\text { surgery } 45 \% \text { had iridectomy } \\
\text { Follow-up of participants was } \\
\text { till 3years after surgery }\end{array}$ & $\begin{array}{l}\text { Measuring of VA, IOP } \\
\text { Examination of optic disc } \\
\text { Administration of MMC as } \\
\text { antimetabolite }\end{array}$ & $\begin{array}{l}88 \% \text { of eyes were examined at } 3 \text { years. } \\
\text { IOP declined from } 29.9 \mathrm{~mm} \mathrm{Hg} \text { to } 14.7 \mathrm{~mm} \mathrm{Hg} \text { at } 3 \\
\text { years, with } 89 \% \text { achieving a reduction of } 25 \% \text { or } \\
\text { more. } \\
\text { The mean c/d ratio increased by only } 0.027 \\
\text { units }(0.66(0.25) \text { to } 0.69(0.22), \mathrm{p}=0.8, \mathrm{n}=13 \\
\text { eyes). The c/d ratio worsened by } 0.05 \text { units or more } \\
\text { in four eyes, improved by } 0.05 \text { or more in three } \\
\text { eyes, and was unchanged in the remainder. } \\
\text { Among the yes with trabeculectomy alone, visual } \\
\text { acuity was essentially unchanged in five } \\
\text { eyes, improved by one or more line in four } \\
\text { eyes, and was worse in eight eyes }\end{array}$ \\
\hline $\begin{array}{l}\text { Mielke C, } \\
\text { Nigeria, } 2003 \\
\text { [24] }\end{array}$ & $\begin{array}{l}154 \text { eyes } \\
101 \\
\text { patients } \\
-\end{array}$ & $\begin{array}{l}\text { Retrospective Trabculectomy } \\
\text { with } 2 \text { groups of patients: } \\
\text { group that received } \\
\text { intraoperative antimetabolite } \\
\text { and control group. Subsequent } \\
\text { surgery for glaucoma and } \\
\text { cataract was noted. } \\
\text { Average follow-up was } \\
17 \pm 2.18 \text { months. Major } \\
\text { outcome measures were an } \\
\text { IOP reduction of more than } \\
30 \% \text { from preoperative levels, } \\
\text { a permanent decrease in } \\
\text { visual acuity of two or } \\
\text { less Snellen-chart lines } \\
\text { from preoperative levels } \\
\text { and: } \\
\text { 1. IOP } 20 \text { mm Hg or less with } \\
\text { or without medication. } \\
2 . \text { IOP less than } 14 \text { mmHg } \\
\text { with or without medication. }\end{array}$ & $\begin{array}{l}\text { Measuring VA and IOP } \\
\text { Administration of } 5 \mathrm{FU} \text { as } \\
\text { antimetabolite }\end{array}$ & $\begin{array}{l}\text { When an IOP of } 20 \mathrm{mmHg} \text { or less was defined as } \\
\text { success, } 76 \% \text { of the } 5 \text {-FU group and } 79 \% \text { of the } \\
\text { control group were successful at } 18 \text { months. } \\
\text { Comparison of survival curves did not show any } \\
\text { significant difference by the log-rank test }(\mathrm{p}=0.55) \text {. } \\
\text { When success was defined as an IOP of } 14 \mathrm{mmHg} \text {, } \\
\text { the probability of success was } 64 \% \text { for the } 5 \text {-FU } \\
\text { group and } 39 \% \text { for the control group at } 18 \text { months. } \\
\text { This difference was significant by the log-rank test } \\
(\mathrm{p}=0.018) \text {. } \\
5.1 \% \text { of the control group and } 8.9 \% \text { for the } 5 \mathrm{FU} \\
\text { group lost more than two lines of Snellen-chart } \\
\text { visual acuity and the difference was not statistically } \\
\text { significant }(\mathrm{p}=0.49) \text {. }\end{array}$ \\
\hline $\begin{array}{l}\text { Nitin Anand, } \\
\text { Nigeria, } 2012 \\
\text { [25] }\end{array}$ & $\begin{array}{l}132 \text { eyes } \\
129 \\
\text { patients } \\
\text { Primary } \\
\text { trabeculect- } \\
\text { omy }\end{array}$ & $\begin{array}{l}\text { Retrospective } 73 \text { eyes had } \\
\text { trabeculectomy with } \\
\text { application of antimetabolite. } \\
\text { Two criteria for success } \\
\text { were used for survival } \\
\text { analyses. IOP of less than } 19 \\
\text { and } 15 \mathrm{mmHg} \text {, a decrease of } \\
20 \% \text { from preoperative IOP } \\
\text { were used for Kaplan-Meier } \\
\text { survival analyses. }\end{array}$ & $\begin{array}{l}\text { Measuring of VA, IOP } \\
\text { Administration of 5FU and } \\
\text { MMC as antimetabolite }\end{array}$ & $\begin{array}{l}\text { The 5-FU group had longer mean follow-up of } \\
53 \pm 26 \text { months than the MMC group }(38 \pm 18 \\
\text { months, } p<0.001) \text {. The MMC group had } \\
\text { significantly lower pressures at all postoperative } \\
\text { visit except between } 30 \text { and } 35 \text { months }(p=0.07) \text {. } \\
\text { The probability of maintaining an IOP less than } 19 \\
\text { mmHg and } 15 \mathrm{mmHg} \text { without additional medication } \\
\text { or needle revisions at } 2 \text { and } 3 \text { years postoperatively } \\
\text { was } 71 \% \text { and } 64 \% \text { respectively for the } 5 \mathrm{FU} \text { group and } \\
81 \% \text { and } 79 \% \text { respectively for the MMC group. } \\
\text { The MMC group had significantly better survival } \\
\text { times, both for IOP less than } 19 \mathrm{~mm} \mathrm{Hg}(\mathrm{p}=0.03) \\
\text { and IOP less than } 15 \mathrm{~mm} \mathrm{Hg}(\mathrm{p}=0.006) \text {. } \\
\text { At last follow up, } 40 \text { eyes }(30.3 \%) \text { had lost more } \\
\text { than } 2 \text { lines of Snellen visual acuity, } 24 \text { from } 5-\mathrm{FU} \\
\text { and } 16 \text { from the MMC group }(\mathrm{p}=0.8) \text {. }\end{array}$ \\
\hline
\end{tabular}

$\mathrm{c} / \mathrm{d}$ ratio $=$ cup-disc ratio; $\mathrm{IOP}=$ intraocular pressure $\mathrm{VA}=$ visual acuity; $5 \mathrm{FU}=5$ fluorouracil $\mathrm{MMC}=$ mitomycin $\mathrm{C} ; \mathrm{POAG}=$ primary open angle glaucoma; $\mathrm{NTG}=$ normal tension glaucoma. 
participants.

- Outcome of the cup-disc (c/d) ratio and the visual field post-operative. The follow-up of the $\mathrm{c} / \mathrm{d}$ was only found in 3 studies. In these cases, the $\mathrm{c} / \mathrm{d}$ ratio was $\leq 0.5$ in $13 \%$ and $\geq 0.8$ in $83 \%$. There was a failure on the $\mathrm{c} / \mathrm{d}$ ratio of 0.9 and this increased by 0.027 units [23].

And for the visual field, there was a follow-up for only one study.

\section{Discussion}

Trabeculectomy is the most common operative procedure for the treatment of medically uncontrolled glaucoma. It remains the mainstay of treatment for black glaucoma patients especially those of African origin due to the unavailability and high cost of topical therapy [26,27].

The findings of our review revealed that rates of IOP between $10 \mathrm{mmHg}-22 \mathrm{mmHg}$ ranged from $61.8 \%$ to $90 \%$ in the reviewed articles. The criteria of the complete success of IOP were different for each study but all of them had significant complete success of more than $50 \%$. Depending on the trabeculectomy with augmentation or not, all of them had a success result despite some authors suggesting that in African patients, a successful outcome of trabeculectomy may be compromised by an aggressive healing response $[28,29]$. Therefore, antimetabolites such as 5-FU or MMC can be used [30] as found by Adegbehingbe in Nigeria in which the mean post-operative IOP in the 5FU-augmented cases was significantly lower compared with the non augmented cases $(p=0.005)$ [16]. A study conducted by Yorston in Kenya found that the placebo group was 2.18 times $(95 \%$ CI 0.67 to 7.15 ) more likely to require additional IOP lowering procedures than the 5-FU group [19]. In another study conducted by Anand et al. in Nigeria trabeculectomy without antimetabolite use appeared to be an effective way to lower the IOP of advanced glaucoma to less than 22 $\mathrm{mmHg}$ but not to less than $16 \mathrm{mmHg}$ [21]. From these results, regardless of the trabeculectomy being with or without augmentation of antimetabolite, combined or not with cataract surgery, it appears to be a good way to lowering the IOP in Africans. The results of this study are consistent with findings from elsewhere, for instance, Ioannis Kyprianou et al. found that with the longest follow-up period, trabeculectomy augmented with MMC under the scleral flap in difficult cases can achieve good long-term IOP control [31]. Leyland $\mathrm{M}$ et al. found that the effect of $5 \mathrm{FU}$ has been reported with conflicting results such as showing no significant effect in other populations [32]. Wang Mei et al. showed that phacotrabeculectomy and trabeculectomy treatments exhibit similar IOP reduction, successful rates, and complications when it comes to treating PACG patients with coexisting cataract [33]. In addition, Vizzeri G and Weinreb RN showed that surgical alternatives combined with cataract extraction may be utilized to achieve a more significant IOP reduction [34].

The results of ROTCHFORD A showed that the success rates of trabeculectomy were lower than those reported in developed countries, the difference may be attributed to differences in surgical technique and postoperative interventions such as suture removal/lysis, manipulation of the bleb, and tailored steroid dosage [35].

Argon laser trabeculoplasty (ALT) may have lower long term IOP lowering effect in blacks than whites [36]. Blacks have higher risk of ALT failure than whites [37]. In any case lasers are hard to come by in African setting.

The VA was unchanged among $19 \%$ to $30 \%$ of the participants in the last follow-up, VA improvement rate was between $36 \%$ to $81.5 \%$ and worsened in $8.9 \%$ to $30.8 \%$ of the participants. Combined surgery produce visual benefit for most patients with similar pressure control to pure trabeculectomy [20]. The large prospective studies such as Ocular Hypertension Treatment Study (OHTS) [38], Collaborative Normal Tension Glaucoma Study (CNTGS)[39] and Early Manifest Glaucoma Treatment Study (EMGTS) [40] have demonstrated that lower IOPs are associated with reduced risk for progresssion of visual field damage and visual loss [41]. Ioannis Kyprianou et al. found the main reason for reduced vision was pre-existing co-morbidity and development of lenticular opacities [31]. In a study conducted by Stalmans et al., no change in visual acuity was noted: visual acuity before and at 1 month postoperatively was 0.67 (0.3) (range $0.01-1)$ and $0.61(0.3)$ (range $0.02-1.0 ; \mathrm{p}=$ $0.25)$ on average [42]. Visual loss of more than two Snellen-chart lines was observed in a significant proportion of patients who had primary trabeculectomy in a Nigerian population [43]. Bekibele found a statistically significant decrease in visual acuity post-operatively [27]. Brian A. et al., Law SK found snuff-out (or severe longterm unexplained vision loss after trabeculectomy with mitomycin C treatment [44-46] and the risk factor for long-term vision loss was preoperative split fixation on VF. Transient vision loss is common and may take up to 2 years for recovery [44].

The results of the review also indicate that the follow-up of the c/d was found in 3 studies. In these cases, the c/d ratio was $\leq 0.5$ in $13 \%$ and $\geq 0.8$ in $83 \%$. There was a failure on the $\mathrm{c} / \mathrm{d}$ result from 0.9 or worse and increasing by 0.027 units [23]. Mielke $\mathrm{C}$ et al showed $70 \%$ of eyes had advanced glaucomatous optic disc cupping or visual field loss affecting central vision [24]. Kotecha and coworkers identified "significant" increases in rim volume at 2 years following surgical operations which produced a fall in pressure of around $30 \%$. The reversal of disc cupping following trabeculectomy can be present up to 2 years after pressure reduction [47]. Reversal of 
optic disc cupping following intraocular pressure reduction is a well known phenomenon [48] and changes seen in juvenile glaucomas are more pronounced than those found in adult patients $[49,50]$. The clinical significance of these disc changes appears to be unclear, although reports have suggested that there may be an associated improvement of visual function that corresponds to this improvement in disc appearance [39,51-54]. But a study by Park et al. described short-term (follow-up of two months) reversal of optic disc cupping documented by Heidelberg Retina Tomograph (HRT) in adult glaucoma patients (mean age of $59.3 \pm 9.1$ years) after IOP reduction following trabeculectomy [55]. And Swinnen et al. documented two young-adult patients (33-year-old and 14-year-old) with reversal of optic disc cupping after trabeculectomy lasted for 6 and 36 months respectively and showed an improvement of cup to disc area ratio on HRT [56].

There was a follow-up for only one study on visual field in our review. Blacks of all ages had worst visual fields than whites when $60^{\circ}$ Humphrey's visual field was tested [57]. The progression of visual field loss is higher in blacks than whites [58]. Visual fields remained stable in $73.3 \%$ of cases during the follow-up period [59]. In any case diagnosis of visual field progression remains difficult, particularly in eyes with advanced field loss, due to long-term fluctuation of fields [60]. A study of Swinnen $\mathrm{S}$ et al. documented two young-adult patients (33-year-old and 14-year-old) who showed an improvement in visual field for at least 3 months after trabeculectomy for the first patient and the second patient for 3 years [56].

The facts that mean IOPs of $14 \mathrm{mmHg}$ can result in stable visual field has been concluded from several major clinical studies $[61,62]$. Moreover, IOP fluctuations are a known risk factor for visual field progression [63]. Anyway careful postoperative follow-up observation of the visual field remains necessary even after successful surgical pressure reduction [64].

The study has the following limitations; the review only included articles of studies conducted in only five African countries as such the findings of the study cannot be generalized to the entire African population. Poor acceptance of the surgery and late presentation of patients to the hospital also affected the outcomes trabeculectomy among the studies included in this review. The IOP at presentation was high in most of the patients [65]. One third of the patients had c: $d$ ratio of 0.9 at presentation [66]. Even those who presented earlier and despite intense effort at health education on the nature of the disease, it was difficult to convince some patients that the eye that could see far well had a potentially sight threatening disease [66]. Peter R Egbert found that patients are often put off or refuse surgery until they have severe vi- sion loss [67]. A Tanzanian study, found that only $46 \%$ of patients accepted trabeculectomy even though they were offered free surgery, hospitalization, and food [2]. In interactions and discussions made by Peter R Egbert with West African ophthalmologists showed that one finds an understandable reluctance to do trabeculectomies because of poor patient acceptance, the difficulty of postoperative care, and uncertain results. In fact, most ophthalmologists do no glaucoma surgery [67]. Another limitation of the study was that only studies published in English language were included in the study. We might have left out some studies conducted in other languages which might have contributed significantly to our study. Furthermore, the duration of follow-up was short and differed across the studies included in the review. The follow-up period was short and drop-out rate was significantly high but these were beyond our control [68]. The problem of loss to follow-up in Africa seems to have started long time ago. In 1979 and 1990, Thommy CP et al. and Verry JD already concluded that "One of the biggest problems in most studies is the lack of adequate follow-up" $[69,70]$.

\section{Conclusion}

Trabeculectomy with or without application of antimetabolite appears to be a good way of lowering the IOP in Africa. In addition, combining trabeculectomy with cataract surgery produces visual benefit for the patients. There is a need for African countries to adopt ways of improving and expanding the duration of follow-up of post-operative patients. More longitudinal studies are also needed on outcomes of trabeculectomy in most of the African countries in order to have enough evidence on the effectiveness of the procedure. Educating the population on the severity of glaucoma is also warranted. Practitioners should also be motivated to do fundoscopy and identify optic disc cupping and refer in time the suspected cases to the ophthalmologists. Furthermore, the practitioners and opthalmologists should be offered continuous training on trabeculectomy.

\section{REFERENCES}

[1] C. Werschnik, C. Schäferhoff, F. W. Wilhelm, et al., "The Problem of Glaucoma in Africa-Progress Report from CAMEROON," Klinische Monatsblatter fur Augenheilkunde, Vol. 222, No. 10, 2005, pp. 832-834. doi: $10.1055 / \mathrm{s}-2005-858462$

[2] H. A. Quigley, R. R. Buhrmann, S. K. West, et al., "Long Term Results of Glaucoma Surgery among Participants in an East African Population Survey," British Journal of Ophthalmology, Vol. 84, No. 8, 2000, pp. 860-864. doi: $10.1136 /$ bjo.84.8.860

[3] A. Sommer, J. M. Tielsch, J. Katz, et al., "Relationship between Intraocular Pressure and Primary Open Angle 
Glaucoma among White and Black Americans," Archives of Ophthalmology, Vol. 109, No. 8, 1991, pp. 1090-1095. doi:10.1001/archopht.1991.01080080050026

[4] M. C. Leske, A. M. Connell, A. P. Schachat, et al., "The Barbados Eye Study: Prevalence of Open Angle Glaucoma," Archives of Ophthalmology, Vol. 112, No. 6, 1994, pp. 821-829. doi:10.1001/archopht.1994.01090180121046

[5] J. D. Verry, A. Foster, R. Wormald, et al., "Chronic Glaucoma in Northern Ghana: A Retrospective Study of 397 Patients," Eye, Vol. 4, Pt. 1, 1990, pp. 115-120. doi:10.1038/eye.1990.14

[6] K. Nouri-Mahdavi, L. Brigatti, M. Weitzman, et al., "Outcomes of Trabeculectomy for Primary Open-Angle Glaucoma," Ophthalmology, Vol. 102, No. 12, 1995, pp. 1760-1769.

[7] R. David, J. Freedman and M. H. Luntz, "Comparative Study of Watsons and Cairns Trabeculectomies in a Black Population with Open Angle Glaucoma," British Journal of Ophthalmology, Vol. 61, No. 2, 1977, pp. 117-119. doi:10.1136/bjo.61.2.117

[8] C. P. Thommy and I. S. Bhar, "Trabeculectomy in Nigerian Patients with Open-Angle Glaucoma," British Journal of Ophthalmology, Vol. 63, No. 9, 1979, pp. 636-642. doi:10.1136/bjo.63.9.636

[9] R. David, J. Freedman and M. H. Luntz, "Comparative Study of Watson's and Cairn's Trabeculectomies in a Black Population with Open Angle Glaucoma," British Journal of Ophthalmology, Vol. 61, No. 2, 1977, pp. 117119. doi:10.1136/bjo.61.2.117

[10] M. R. Wilson, "Posterior Lip Sclerectomy vs Trabeculectomy in West Indian Blacks," Archives of Ophthalmology, Vol. 107, No. 11, 1989, pp. 1604-1608. doi:10.1001/archopht.1989.01070020682027

[11] M. E. Gyasi, W. M. K. Amoaku, O. A. Debrah, et al., "Outcome of Trabeculectomies without Adjunctive Antimetabolites," Ghana Medical Journal, Vol. 40, No. 2, 2006, pp. 39-44.

[12] L.-A. Lim, P. Chindasub and N. Kitnarong, "The Surgical Outcome of Primary Trabeculectomy with Mitomycin C and A Fornix-Based Conjunctival Flap Technique in Thailand," Journal of the Medical Association of Thailand, Vol. 91, No. 10, 2008, pp. 1551-1557.

[13] M. V. Boland, A.-M. Ervin, D. S. Friedman, et al., "Comparative Effectiveness of Treatments for Open-Angle Glaucoma: A Systematic Review for the U.S. Preventive Services Task Force," Annals of Internal Medicine, Vol. 158, No. 4, 2013, pp. 271-279.

doi:10.7326/0003-4819-158-4-201302190-00008

[14] D. Moher, D. J. Cook, S. Eastwood, et al., "Improving the Quality of Reports of Meta-Analyses of Randomised Controlled Trials: the QUOROM Statement. Quality of Reporting of Meta-Analyses," Lancet, Vol. 354, No. 9193, 1999; pp. 1896-1900. doi:10.1016/S0140-6736(99)04149-5

[15] A. Lawan, "Pattern of Presentation and Outcome of Surgical Management of Primary Open Angle Glaucoma in Kano, Northern Nigeria," Annals of African Medicine, Vol. 6, No. 4, 2007, pp. 180-185. doi:10.4103/1596-3519.55700

[16] B. O. Adegbehingbe and T. Majemgbasan, "A Review of Trabeculectomies at a Nigerian Teaching Hospital," Ghana Medical Journal, Vol. 41, No. 4, 2007, pp. 176-180.

[17] T. Manners, J. F. Salmon and A. Barron, "Trabeculectomy with Mitomycin $\mathrm{C}$ in the Treatment of Post-Traumatic Angle Recession Glaucoma," British Journal of Ophthalmology, Vol. 85, No. 2, 2001, pp. 159-163. doi:10.1136/bjo.85.2.159

[18] J. Kabiru, R. Bowman, M. Wood, et al., "Audit of Trabeculectomy at a Tertiary Referral Hospital in East Africa," Journal of Glaucoma, Vol. 14, No. 6, 2005, pp. 432-434. doi:10.1097/01.ijg.0000185617.98915.36

[19] D. Yorston and P. T. Khaw, "A Randomised Trial of the Effect of Intraoperative 5-FU on the Outcome of Trabeculectomy in East Africa," British Journal of Ophthalmology, Vol. 85, No. 9, 2001, pp. 1028-1030. doi:10.1136/bjo.85.9.1028

[20] R. J. C. Bowman, A. Hay, M. L. Wood, et al., "Combined Cataract and Trabeculectomy Surgery for Advanced Glaucoma in East Africa: Visual and Intra-Ocular Pressure Outcomes," Eye, Vol. 24, 2010, pp. 573-577. doi:10.1038/eye.2009.132

[21] N. Anand, C. Mielke and V. K. Dawda, "Trabeculectomy Outcomes in Advanced Glaucoma in Nigeria," Eye, Vol. 15, 2001, pp. 274-278. doi:10.1038/eye.2001.93

[22] A. O. Ashaye and O. O. Komolafe, "Post-Operative Complication of Trabeculectomy in Ibadan, Nigeria: Outcome of 1-Year Follow-Up," Eye, Vol. 23, 2009, pp. 448-452. doi:10.1038/sj.eye.6702979

[23] H. A. Quigley, R. R. Buhrmann and S. K. West, "Long Term Results of Glaucoma Surgery among Participants in an East African Population Survey," British Journal of Ophthalmology, Vol. 84, No. 8, 2000, pp. 860-864. doi:10.1136/bjo.84.8.860

[24] C. Mielke, V. K. Dawda and N. Anand, "Intraoperative 5-Fluorouracil Application during Primary Trabeculectomy in Nigeria: A Comparative Study," Eye, Vol. 17, 2003, pp. 829-834. doi:10.1038/sj.eye.6700492

[25] N. Anand and V. K. Dawda, "A Comparative Study of Mitomycin C and 5-Fluorouracil Trabeculectomy in West Africa," Middle East African Journal of Ophthalmology, Vol. 19, No. 1, 2012, pp. 147-152. doi:10.4103/0974-9233.92132

[26] A. M. Agbeja-Bayeroju, M. Omoruyi and E. T. Owoaje, "Effectiveness of Trabeculectomy on Glaucoma Patients in Ibadan," African Journal of Medicine and Medical Sciences, Vol. 30, No. 1-2, 2001, pp. 39-42.

[27] C. O. Bekibele, "Evaluation of 56 Trabeculectomy Operations at Ago-Iwoye, Ogun State, Nigeria," West African Journal of Medicine, Vol. 20, No. 3, 2001, pp. 223-226.

[28] D. Broadway, I. Grierson and R. Hitchings, "Racial Differences in the Results of Glaucoma Filtration Surgery: Are Racial Differences in the Conjunctival Cell Profile Important?" British Journal of Ophthalmology, Vol. 78, No. 6, 1994, pp. 466-475. doi:10.1136/bjo.78.6.466

[29] F. Ederer, D. A. Gaasterland, L. G. Dally, J. Kim, P. C. Van Veldhuisen, B. Blackwell, et al., "The Advanced 
Glaucoma Intervention Study (AGIS): 13. Comparison of Treatment Outcomes within Race: 10-Year Results," Ophthalmology, Vol. 111, No. 4, 2004, pp. 651-664. doi:10.1016/j.ophtha.2003.09.025

[30] C. Akarsu, M. Onol and B. Hasanreisoglu, "Postoperative 5-Fluorouracil versus Intraoperative Mitomycin $\mathrm{C}$ in High-Risk Glaucoma Filtering Surgery: Extended Follow up," Clinical \& Experimental Ophthalmology, Vol. 31, No. 3, 2003, pp. 199-205. doi:10.1046/j.1442-9071.2003.00645.x

[31] I. Kyprianou, M. Nessim, V. Kumar, et al., "Long-Term Results of Trabeculectomy with Mitomycin C Applied under the Scleral Flap," International Ophthalmology, Vol. 27, No. 6, 2007, pp. 351-355. doi:10.1007/s10792-007-9092-3

[32] M. Leyland, P. Bloom, E. Zinicola, et al., "Single Intraoperative Application of 5-Fluorouracil versus Placebo in Low-Risk Trabeculectomy Surgery: A Randomized Trial," Journal of Glaucoma, Vol. 10, No. 6, 2001, pp. 452-457. doi:10.1097/00061198-200112000-00003

[33] M. Wang, M. Fang, Y.-J. Bai, et al., "Comparison of Combined Phacotrabeculectomy with Trabeculectomy Only in the Treatment of Primary Angle-Closure Glaucoma," Chinese Medical Journal, Vol. 125, No. 8, 2012, pp. 1429-1433.

[34] G. Vizzeri and R. N. Weinreb, "Cataract Surgery and Glaucoma," Current Opinion in Ophthalmology, Vol. 21, No. 1, 2010, pp. 20-24. doi:10.1097/ICU.0b013e328332f562

[35] A. Rotchford, "What Is Practical in Glaucoma Management?" Eye, Vol. 19, 2005, pp. 1125-1132. doi:10.1038/sj.eye.6701972

[36] A. L. Schwartz, D. C. Love and M. A. Schwartz, "Long Term Follow up of Argon Laser Trabeculoplasty for Uncontrolled Open Angle Glaucoma," Archives of Ophthalmology, Vol. 103, No. 10, 1985, pp. 1482-1484. doi:10.1001/archopht.1985.01050100058018

[37] AGIS, "The Advanced Glaucoma Intervention Study (AGIS): 9. Comparison of Glaucoma Outcomes in Black and White Patients within Treatment Groups," American Journal of Ophthalmology, Vol. 132, No. 3, 2001, pp. 311-320. doi:10.1016/S0002-9394(01)01028-5

[38] M. A. Kass, D. K. Heuer, E. J. Higginbotham, et al., "The Ocular Hypertension Treatment Study: A Randomized Trial Determines that Topical Ocular Hypotensive Medication Delays or Prevents the Onset of Primary OpenAngle Glaucoma," Archives of Ophthalmology, Vol. 120, No. 6, 2002, pp. 701-713. doi:10.1001/archopht.120.6.701

[39] Collaborative Normal-Tension Glaucoma Study Group, "Comparison of Glaucomatous Progression between Untreated Patients with Normal-Tension Glaucoma and Patients with Therapeutically Reduced Intra Ocular Pressures," American Journal of Ophthalmology, Vol. 126, No. 4, 1998, pp. 487-497. doi:10.1016/S0002-9394(98)00223-2

[40] A. Heijl, M. C. Leske, B. Bengtsson, et al., "Reduction of Intraocular Pressure and Glaucoma Progression: Results from the Early Manifest Glaucoma Trial," Archives of
Ophthalmology, Vol. 120, No. 10, 2002, pp. 1268-1279. doi:10.1001/archopht.120.10.1268

[41] P. S. Mahar and A. D. Laghari, "Intraocular Pressure Control and Post Operative Complications with Mitomycin-C Augmented Trabeculectomy in Primary Open Angle and Primary Angle-Closure Glaucoma," Pakistan Journal of Ophthalmology, Vol. 27, No. 1, 2011, pp. 3539.

[42] I. Stalmans, A. Gillis, A.-S. Lafaut, et al., "Safe Trabeculectomy Technique: Long Term Outcome," British Journal of Ophthalmology, Vol. 90, No. 1, 2006, pp. 4447. doi:10.1136/bjo.2005.072884

[43] B. J. Gonzalez, M. I. Gonzalez, G. M. Gonzalez, R. Marin, A. Varas and T. M. Montesinos, "Non-Penetrating Deep Trabeculectomy Treated with Mitomycin C without Implant. A Prospective Evaluation of 55 Cases," French Journal of Ophthalmology, Vol. 27, No. 8, 2004, pp. 907911.

[44] A. B. Francis, B. Hong and J. Winarko, "Vision Loss and Recovery after Trabeculectomy Risk and Associated Risk Factors," Archives of Ophthalmology, Vol. 129, No. 8, 2011, pp. 1011-1017. doi:10.1001/archophthalmol.2011.182

[45] S. P. Aggarwal and S. Hendeles, "Risk of Sudden Visual Loss Following Trabeculectomy in Advanced Primary Open-Angle Glaucoma," British Journal of Ophthalmology, Vol. 70, No. 2, 1986, pp. 97-99. doi:10.1136/bjo.70.2.97

[46] S. K. Law, A. M. Nguyen, A. L. Coleman and J Caprioli, "Severe Loss of Central Vision in Patients with Advanced Glaucoma Undergoing Trabeculectomy," Archives of Ophthalmology, Vol. 125, No. 8, 2007, pp. 1044-1050. doi:10.1001/archopht.125.8.1044

[47] A. Kotecha, D. Siriwardena and F. W. Fitzke, "Optic Disc Changes Following Trabeculectomy: Longitudinal and Localisation of Change," British Journal of Ophthalmology, Vol. 85, No. 8, 2001, pp. 956-961. doi:10.1136/bjo.85.8.956

[48] M. R. Lesk, G. L. Spaeth, A. Azuaro-Blanco, et al., "Reversal of Optic Disc Cupping after Glaucoma Surgery Analyzed with a Scanning Laser Tomograph," Ophthalmology, Vol. 106, No. 5, 1999, pp. 1013-1018. doi:10.1016/S0161-6420(99)00526-6

[49] R. N. Shaffer and J. Hetherington Jr., "The Glaucomatous Disc in Infants. A Suggested Hypothesis for Disc Cupping," Transactions of the American Academy of Ophthalmology, Vol. 73, No. 5, 1969, pp. 923-935.

[50] A. L. Robin and H. A. Quigley, "Transient Reversible Cupping in Juvenile-Onset Glaucoma," American Journal of Ophthalmology, Vol. 88, No. 3, 1979, pp. 580-584.

[51] L. J. Katz, G. L. Spaeth, L. B. Cantor, et al., "Reversible Optic Disk Cupping and Visual Field Improvement in Adults with Glaucoma," American Journal of Ophthalmology, Vol. 107, No. 5, 1989, pp. 485-492.

[52] C. S. Tsai, D. H. Shin, J. Y. Wan, et al., "Visual Field Global Indices in Patients with Reversal of Glaucomatous Cupping after Intraocular Pressure Reduction," Ophthalmology, Vol. 98, No. 9, 1991, pp. 1412-1419. 
[53] G. L. Spaeth, "The Effect of Change in Intraocular Pressure on the Natural History of Glaucoma: Lowering Intraocular Pressure in Glaucoma can Result in Improvement of Visual Fields," Transactions of the Ophthalmological Societies of the United Kingdom, Vol. 104, No. 3, 1985, pp. 256-264.

[54] E. Yildirim, A. H. Bilge and S. Ilker, "Improvement of Visual Field Following Trabeculectomy for Open Angle Glaucoma," Eye, Vol. 4, No. 1, 1990, pp. 103-106. doi:10.1038/eye.1990.12

[55] K. H. Park, D. M. Kim and D. H. Youn, "Short-Term Change of Optic Nerve Head Topography after Trabeculectomy in Adult Glaucoma Patients as Measured by Heidelberg Retina Tomography," Korean Journal of Ophthalmology, Vol. 11, No. 1, 1997, pp. 1-6.

[56] S. Swinnen, I. Stalmans and T. Zeyen, "Reversal of Optic Disc Cupping with Improvement of Visual Field and Stereometric Parameters after Trabeculectomy in Young Adult Patients. (Two Case Reports)," Bulletin de la Société Belge d'Ophtalmologie, Vol. 316, 2010, pp. 4957.

[57] G. S. Rubin, S. K. West, B. Munoz, et al., "A Comprehensive Assessment of Visual Impairment in a Population of Older Americans. The SEE Study. Salisbury Eye Evaluation Project," Investigative Ophthalmology \& Visual Science, Vol. 38, No. 3, 1997, pp. 557-568.

[58] R. Wilson, T. M. Richardson, E. Hertzmark, et al., "Race as a Risk Factor for Progressive Glaucomatous Damage," Annals of Ophthalmology, Vol. 17, No. 10, 1985, pp. 653-659.

[59] H. J. Beckers, K. C. Kinders and C. A. Webers, "Five Year Results of Trabeculectomy with Mitomycine C," Graefe's Archive for Clinical and Experimental Ophthalmology, Vol. 241, No. 2, 2003, pp. 106-110. doi:10.1007/s00417-002-0621-5

[60] R. J. Boeglin, J. Caprioli and M. Zuluaf, "Long-Term Fluctuation of Visual Field in Glaucoma," American Journal of Ophthalmology, Vol. 113, No. 4, 1992, pp. 396-400.

[61] C. Migdal, W. Gregory and R. Hitchings, "Long-Term Functional Outcome after Early Surgery Compared with Laser and Medicine in Open-Angle Glaucoma," Ophthalmology, Vol. 101, No. 10, 1994, pp. 1651-1656.
[62] AGIS Investigators, "The Advanced Glaucoma Intervention Study (AGIS): 7. The Relationship between Control of Intraocular Pressure and Visual Field Deterioration. The AGIS Investigators," American Journal of Ophthalmology, Vol. 130, No. 4, 2000, pp. 429-440. doi:10.1016/S0002-9394(00)00538-9

[63] K. Nouri-Mahdavi, D. Hoffman, A. L. Coleman, et al., "Predictive Factors for Glaucomatous Visual Field Progression in the Advanced Glaucoma Intervention Study," Ophthalmology, Vol. 111, No. 9, 2004, pp. 1627-1635. doi:10.1016/i.ophtha.2004.02.017

[64] E. B. Werner, S. M. Drance and M. Schulzer, "Trabeculectomy and the Progression of Glaucomatous Visual Field Loss," Archives of Ophthalmology, Vol. 95, No. 8, 1977, pp. 1374-1377. doi:10.1001/archopht.1977.04450080084008

[65] A. Sommer, J. M. Tielsch, J. Katz, et al., "Relationship between Intraocular Pressure and Primary Angle Glaucoma among White and Black Americans," The Baltimore Eye Survey," Archives of Ophthalmology, Vol. 109, No. 8, 1991, pp. 1090-1095.

[66] H. A. Quigley, E. M. Addicks, W. R. Green and A. E. Maumenee, "Optic Nerve Damage in Human Glaucoma. II. The Site of Injury and Susceptibility to Damage," Archives of Ophthalmology, Vol. 99, No. 4, 1981, pp. 635-649. doi:10.1001/archopht.1981.03930010635009

[67] P. R. Egbert, "Glaucoma in West Africa: A Neglected Problem," British Journal of Ophthalmology, Vol. 86, No. 2, 2002, pp. 131-132. doi:10.1136/bjo.86.2.131

[68] M. E. Gyasi, W. M. K. Amoaku, O. A. Debrah, et al., "Outcome of Trabeculectomies without Adjunctive Antimetabolites," Ghana Medical Journal, Vol. 40, No. 2, 2006, pp. 39-44.

[69] C. P. Thommy and I. S. Bhar, "Trabeculectomy in Nigerian Patients with Open-Angle Glaucoma," British Journal of Ophthalmology, Vol. 63, No. 9, 1979, pp. 636-642. doi:10.1136/bjo.63.9.636

[70] J. D. Verry, A. Foster, R. Wormald, et al., "Chronic Glaucoma in Northern Ghana: A Retrospective Study of 397 Patients," Eye, Vol. 4, No. 1, 1990, pp. 115-120. doi:10.1038/eye.1990.14 